\title{
SORJAVIZSGÁLATI MÉRŐSZÁMOK ÖSSZEHASONLÍTÓ ELEMZÉSE SZÉNSZÁLLAL ERŐSÍTETT POLIMER (CFRP) KOMPOZITOKBAN
}

\section{A COMPARATIVE ANALYSIS OF BURR MEASURES IN CARBON FIBRE REINFORCED POLYMER (CFRP) COMPOSITES}

\author{
Poór Dániel István ${ }^{1}$, Geier Norbert ${ }^{1 *}$, Pereszlai Csongor ${ }^{1}$, Balázs Barnabás Zoltán ${ }^{1}$ \\ ${ }^{1}$ Gyártástudomány és -technológia Tanszék, Gépészmérnöki Kar, Budapesti Müszaki és \\ Gazdaságtudományi Egyetem, Magyarország \\ https://doi.org/10.47833/2021.1.ENG.008
}

\section{Kulcsszavak:}

CFRP

Fúrás

Sorja

Keywords:

CFRP

Drilling

Burr

\section{Cikktörténet:}

Beérkezett: 2021.január 14.

Átdolgozva: 2021. április 20.

Elfogadva 2021.április 24.

\section{Összefoglalás}

A szénszállal erősített polimer (CFRP) kompozitok forgácsolása során képződő sorja vizsgálatának és jellemzésének számos módszere és mérőszáma terjedt el, az ezzel kapcsolatos szakirodalmat azonban terminológiai és módszertani inkonzisztencia jellemzi. Ebben a rövid áttekintő cikkben a legelterjedtebb CFRP sorjamérőszámok csoportositása, elemzése és értékelése történik.

\begin{abstract}
Nowadays, numerous measurement and evaluation methods and measures of machining induced burr in carbon fibre reinforced polymer (CFRP) are applied; however, the burr evaluation terminology and methodology is inconsistent. In this short review, the key burr-measures are classified, analysed and discussed.
\end{abstract}

\section{Bevezetés}

A szénszállal erősített polimer (CFRP) kompozitok alkalmazásának elterjedése a 20. század második felétöl rohamosan növekszik [1]. Az CFRP kiváló fajlagos mechanikai tulajdonságainak és méretstabilitásának köszönhetően előszeretettel alkalmazott szerkezeti anyag a „high-tech” szektorokban [2]. A jellemző szerelési megoldások, valamint a szigorú alak- és mérettürések miatt sokszor elengedhetetlen bizonyos forgácsolási müveletek alkalmazása annak ellenére, hogy a térhálós mátrixú CFRP alkatrészek közel végleges formára laminálhatók/préselhetők. A CFRP kompozitok inhomogenitása és anizotropiája, valamint a szénszálak erősen abrazív hatása miatt nehezen forgácsolható anyagnak tekintjük öket [3].

A CFRP forgácsolás során keletkező sorja szerelhetőségi nehézségeket, esztétikai hibákat és további anyagkárosodásokat okozhat, ennélfogva keletkezési mechanizmusainak és geometriai jellemzőinek vizsgálata erősen indokolt. A sorjaképződésre a szerszámgeometria, a forgácsolási paraméterek, a szálvágási szög $(\theta)$, valamint a megmunkálási környezet geometriai kényszerei (pl. támasztó lemez alkalmazása) szignifikáns hatással vannak. Támasztó lemez alkalmazása nélkül a szélső kompozit rétegek lehámozódása történhet meg, ami rétegelváláshoz (delaminációhoz) és

Kapcsolattartó szerző. Tel.: +3614632641

E-mail cím: geier.norbert@gpk.bme.hu 
sorjaképződéshez vezethet. A szerszám túl nagyméretü éllekerekítési sugarának esetében a szerszám hajlamosabb kihajlítani, mint sem elvágni az erősítőszálakat, amely jelentős sorjaformációt indukálhat. Ezen felül, egyes kedvezötlen szálvágási szögek $\left(\theta=135^{\circ} \pm \delta\right.$, ahol $\delta$ környezetfüggő paraméter) esetében a forgácsképződési mechanizmust a makroméretű repedések jellemzik, a szerszám az erősítő szálakat kihajlítja, majd a szálak visszarugózásának következtében sorja képződik [4].

A CFRP kompozitok forgácsolása során fellépő sorja karakterisztikájához, geometriai jellemzőjéhez és mérőszámaihoz kapcsolódó terminológiában jelentős inkonzisztencia figyelhető meg.

Ezen áttekintő cikk fő célja a hazai és nemzetközi szakirodalomban alkalmazott, a CFRP kompozitok fúrása során keletkező sorja jellemzésére szolgáló mérőszámok csoportosítása, ismertetése és elemzése.

\section{Sorja geometriai jellemzői}

A forgácsolás során el nem távolított anyagfelesleget összetételétöl és helyétöl függően számos megnevezéssel illetik: (i) sorja, (ii) vágatlan szál, (iii) vágatlan mátrixanyag, valamint (iv) delamináció. Jelen áttekintő cikk szerzői - Beier [5] munkájában írtakkal egyetértésben - a terminológiai egységesség céljából minden, a nominális geometriához képest mérhetően eltérő anyagtöbbletet sorja elnevezéssel illetik. Az egyes sorját jellemző mérőszámok pontos meghatározása érdekében a sorjakarakterisztika geometria jellemzőinek egzakt meghatározása szükséges. Ezen változatos geometria jellemzők (ahogyan az 1. ábra is illusztrálja) a következök: sorjahossz, sorjamagasság. sorjaszélesség, a sorja kerülete (kontúrja), a sorja területe és a sorjaképződmények száma.

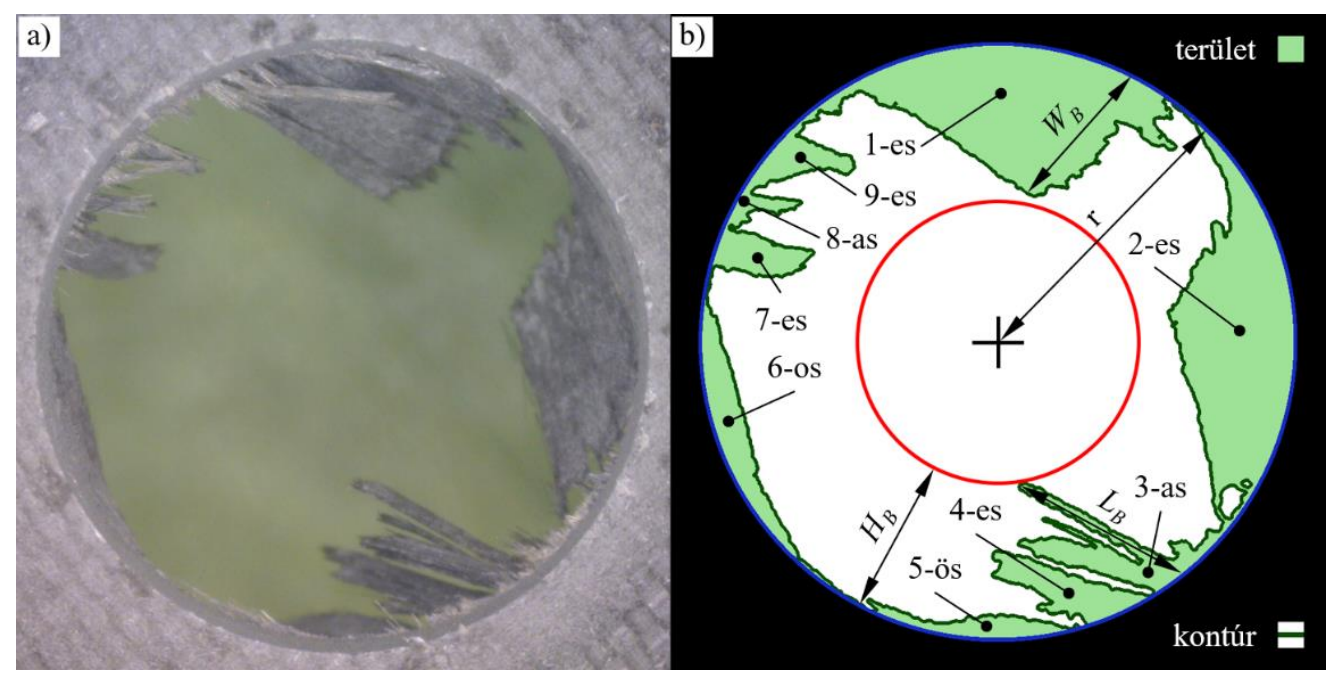

1. ábra. Sematikus ábra a sorjajellemzőkről egy CFRP kompozitba készített furat esetében (a) digitális mikroszkóppal készített eredeti kép, (b) a sorja feldolgozott (szegmentált) képe

\section{Sorja mérőszámai}

Ezen fejezetben a szakirodalomban fellelhető leggyakrabban használt sorjamérőszámokat csoportosítottuk a mérőszámgenerálás bonyolultsága alapján, továbbá értékeltük őket az alkalmazhatóságuk szempontjából.

\subsection{Egyszerű sorjamérőszámok}

Az egyszerű sorjamérőszámok bizonyos esetekben kedvezően alkalmazhatók a forgácsolási technológia minősítésére, valamint a gyártott munkadarab kvalifikációjára. Az egyszerü vizuális elemzés és a sorjaképződmények számának meghatározása sok esetben nem igényel speciális berendezést, azonban nem szolgáltatnak reprodukálható és kvalitatív eredményeket. Az egyszerü vizuális vizsgálat során a megmunkált gyártmány közvetlen vizsgálata, vagy a forgácsolt alaksajátosságról készített (pl. optikai úton, vagy röntgengép segítségével) kép elemzése történik 
[6]. Az egyszerű vizuális vizsgálat eredménye $\left(I_{b}\right)$ nagyban függ a mérőszemélyzet tapasztaltságától, ennek a szubjektív tényezőnek köszönhetően nem egzakt kvalitatív mérőszámként értelmezhető az $I_{b}$ (pl.: $I_{b, 1}=\left\{\right.$ jelentősen sorjásodott a belépő furatkontúr\}; $I_{b, 2}=\{$ szerelhetőséget jelentősen nem befolyásoló mennyiségű sorja képződött a kilépő furatkontúron\}), így a különböző helyeken és/vagy időben végzett mérési eredmények nehezen összehasonlíthatók.

A sorjaképződmények száma $\left(N_{b}\right)$ egy egzakt, kvantitatív mérőszám, amely teljes összehasonlíthatóságot biztosít a különböző méretű alaksajátosságok között (méretfüggetlenségének köszönhetően). A sorja karakterisztikájáról nem hordoz információt az $N_{b}$ kvantitatív jellege miatt, ezért további vizsgálatok szükségesek a gyártott alkatrész alkalmazhatóságának és az esetleges sorjaeltávolítási műveletek meghatározására. A sorjaképződmények számlálása nem minden esetben igényel digitális kiértékelő szoftvert, azonban a vizsgálat eredményének pontossága nagy mértékben növelhető az automatizált algoritmusok használatával. Voß és munkatársai [7] megalkottak egy újszerü összetett mérőszámot, amely méröszám generálása során többek között a digitális optikai mikroszkóppal vizsgált furat sorjaképződményeinek számát is figyelembe vették. Az 1. egyenlet segítségével transzformálták az $N_{b}$ értékét, aminek az eredménye a sorjaképződmények fajlagos száma $\left(F_{b n}\right)$ elnevezésủ mérőszám lett. A szerzők szerint ez az egyenlet más geometriák esetében finomhangolásra szorul, mivel a lineáris gradiens (1/15) és $k$ környezetparaméter ideális értéke függ a furat átmérőjétöl és a forgácsolási körülményektöl (szerszám élgeometria, technológiai paraméterek, szálirány stb.).

$$
F_{b n}=\tanh \left(\frac{\left(N_{b}\right)^{k}}{15}\right)
$$

\subsection{Hosszúság alapú sorjamérőszámok}

A hosszúság alapú sorjamérőszámok alkalmazása széleskörüen elterjedt az iparban, köszönhetően a mérési módszerek (általában optikai mérések mikroszkóppal) egyszerüsége és költséghatékonysága miatt. A hosszúság, szélesség, magasság és kerület sorjakarakterisztikai geometriai jellemzőket vizsgáló mérőszámok a teljes sorjaképződmény egy részletét jellemzik csak, ezért a forgácsolt alaksajátosság teljes kvalitatív jellemzésére és a sorjakarakterisztika meghatározására nem alkalmasak.

A sorjahossz $\left(L_{b}\right)$ a maximális lineáris távolság a sorjatő és a sorjavég között (lásd 1. ábra) [8], [9]. Az $L_{b}$ hasznos információval szolgálhat a szerelhetőség vizsgálata során, azonban a sorjakarakterisztikára nem ad egyértelmű utalást. A különböző geometriával rendelkező alaksajátosságok egymással nem összehasonlíthatók ezzel a mérőszámmal (hiszen pl. az azonos sorjahossz eltérő módon befolyásolja a szerelhetőséget különböző átmérőjü furatok esetében).

Az XY síkban (a furat síkjában) értelmezett sorjamagasság $\left(H_{b}\right)$ a forgácsolt alaksajátosság felülete és a sorjavég közötti távolság a felület normálisára vett irányban (lásd 1. ábra) [10], [11]. A $Z$ irányú (furattengely irányú) sorjamagasság $\left(H_{b z}\right)$ is gyakran értelmezett mérőszám, mely a sorjavég és a munkadarab felszíne között mérendő a távolsággal egyezik meg. A $H_{b z}$ mérőszámot gyakran alkalmazzák CFRP/Fém kompozit szendvicsszerkezetek minőségi értékelésére [12], [13].

A sorjaszélesség $\left(W_{b}\right)$ adott sorjazónán belül értelmezett szálirányra meröleges legnagyobb távolság (lásd 1. ábra) [14]. A $W_{b}$ nagy mértékben függ a sorján belüli mérés helyétöl, ezért egyértelmüen meg kell határozni a mérés helyét. A többi hosszúságalapú sorjamérőszám előnyei és hátrányai a $W_{b}$ esetében is érvényesek.

A kontúr sorjafaktor $\left(F_{b c}\right)$ meghatározása során a forgácsolt geometria kontúrjának és a nominális alaksajátosság kerületének összehasonlítása történik a 2. egyenletben látható módon [14], [15]. A mérőszám segítségével következtetéseket lehet tenni a felületintegritásra és a minőségre, azonban egzakt karakterisztikai állításokat nem lehet vele tenni. A különböző méretü alaksajátosságok összehasonlíthatóak $a z F_{b c}$ segítségével, hiszen arányosítás történik egy nominális értékhez.

$$
F_{b c}=\frac{C_{b^{-}} C_{n o m}}{C_{n o m}} \cdot 100
$$


Ahol: $F_{b c}(\%)$ a kontúr sorjafaktor, $C_{b}(\mathrm{~mm})$ a forgácsolt furat kontúrja és $C_{n o m}(\mathrm{~mm})$ a nominális furat kerülete.

\subsection{Területalapú sorjamérőszámok}

A területalapú sorjamérőszámok egzakt információval szolgálnak a sorja kétdimenziós leképezésének területéröl. Ezen sorjamérőszámokat a kutatók általában más területalapú paraméterekhez arányosítják, így biztosítva a különböző geometriák közötti összehasonlíthatóságot. Ezen mérőszámok a sorjakaraterisztikát (pl. sorjapozíció, sorjatípus) azonban nem jellemzik.

A sorja területének $\left(A_{b}\right)$ mérésekor a forgácsolt geometriáról készített képen a sorja által elfoglalt terület pixeleinek számlálása, majd arányosítása történik (2e. ábra) [11], [16]. Az $A_{b}$ kvantitatív mérőszám a sorja elhelyezkedésére, valamint karakterisztikájára nem ad egyértelmü információt, továbbá különböző méretű geometriák esetében más kvalitatív jelentőséggel bír az azonos értékű mérőszám. Ez utóbbi hiányosság kiküszöbölhető a nominális geometriához történő fajlagosítással. A sorja területe a közvetlen mérésen kívül közvetett számítással is megkapható, ahogyan a 3. egyenletben is látható [17]. A közvetett módszer elönye, hogy a sorjamentes terület meghatározása kisebb hibával terhelt, mint a sorja kiterjedésének meghatározása.

$$
A_{b}=A_{\text {nom }}-A_{\text {free }}
$$

Ahol: $A_{b}\left(\mathrm{~mm}^{2}\right)$ a sorja területe, $A_{\text {nom }}\left(\mathrm{mm}^{2}\right)$ a nominális furat területe és $A_{\text {free }}\left(\mathrm{mm}^{2}\right)$ a sorjamentes területe a furatnak.
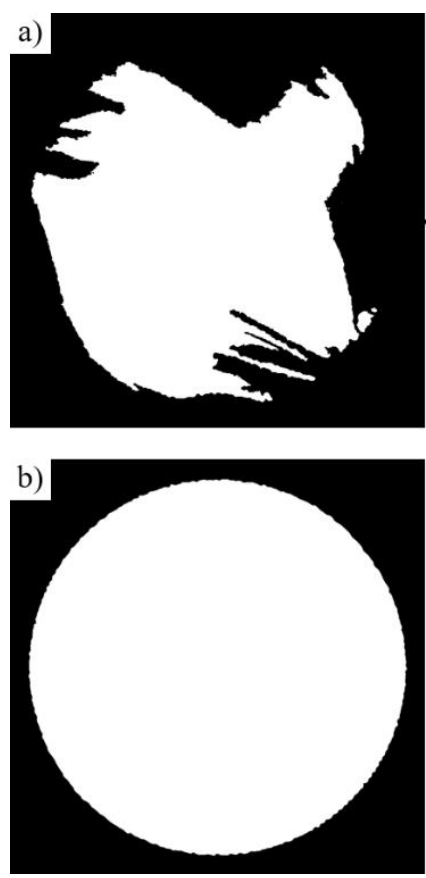

d)
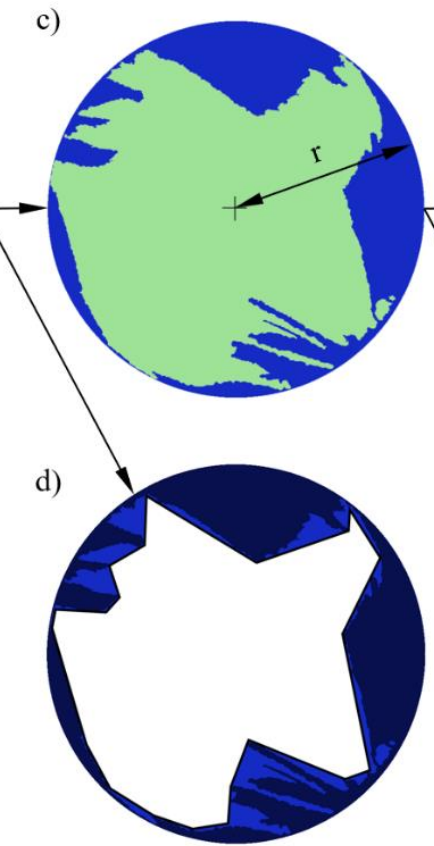

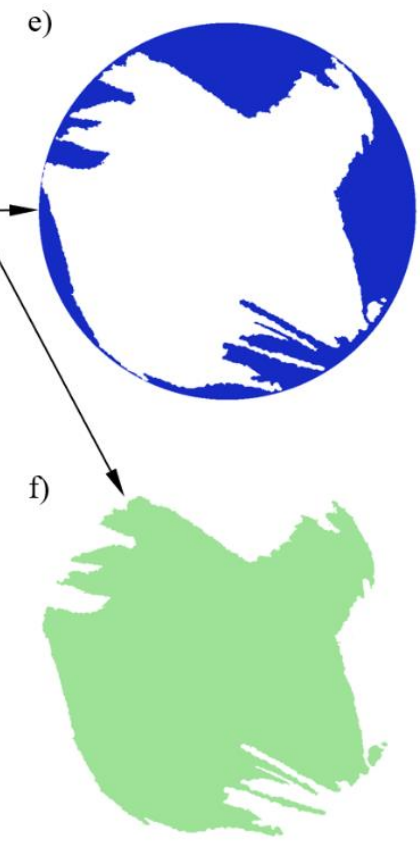

e)

2. ábra. Sematikus ábra a terület alapú sorjaméröszámok digitális képfeldolgozással történő előállításáról: (a) eredeti binarizált furat kép; (b) binarizált névleges furat; (c) sorjafaktor magyarázata; (d) sorjacsoportok területe $\left(A_{b g}\right) ;(e)$ sorja területe $\left(A_{b}\right) ;(f)$ a furat sorjamentes területe $\left(A_{\text {free }}\right)$

A sorjacsoportok területének $\left(A_{b g}\right)$ meghatározása hasonló módszerrel történik, mint az $A_{b}$ esetében, azonban az egymás környezetében lévő sorjaképződmények csoportosításra kerülnek és a befoglaló területük kerül meghatározásra (2d. ábra) [18]. A mérőszámgenerálás gyorsabban történhet, mint a sorja területének esetében, azonban a mérés pontossága kisebb (a sorjaképződmények közötti üres terület figyelmen kívül hagyása miatt).

A sorjafaktor $\left(F_{b}\right)$ mérőszám meghatározása során a sorja területét az ideális furat területéhez arányosítjuk, amelyet a megmunkált geometria kontúrjára illesztett legkisebb köré írható körrel határozhatunk meg (lásd 2c. ábra) [7], [15], [19]. A mérőszámgenerálás az 4. egyenlet alapján 
történik. A mérőszám előnye, hogy a különböző méretű és geometriájú alaksajátosságok összehasonlíthatók, továbbá a mérőszámra egyedül a sorja rendelkezik befolyásoló hatással, a technológiából adódó egyéb hibák kevésbé jelennek meg. A mérőszám a sorja elhelyezkedéséről és karakterisztikájáról nem ad egyértelmü információt, ezért további vizsgálatok lehetnek szükségesek pl. a sorjaeltávolítási müvelet primer információinak meghatározására.

$$
F_{b}=\frac{A_{\text {nom }}-A_{\text {free }}}{A_{\text {nom }}} \cdot 100=\frac{A_{b}}{A_{\text {nom }}} \cdot 100
$$

Ahol: $F_{b}(\%)$ a sorjafaktor, $A_{\text {nom }}\left(\mathrm{mm}^{2}\right)$ a nominális furat területe, $A_{\text {free }}\left(\mathrm{mm}^{2}\right)$ a sorjamentes területe a furatnak és $A_{b}\left(\mathrm{~mm}^{2}\right)$ a sorja területe.

A sorjamentes faktor $\left(F_{b f}\right)$ a furat sorjamentes területének és az ideális alaksajátosság területének összehasonlításával számítódik (2c. ábra és 5. egyenlet) [20], [21]. Az $F_{b f}$ mérőszám meghatározásakor az ideális terület a nemzetközi szakirodalomban általában egy etalon furat segítségével történik. $A z$ arányosításnak köszönhetően a különböző geometriák összehasonlíthatók, azonban ez a mérőszám sem ad egzakt információt a sorjalokációról és karakterisztikáról. A mérőszámgenerálás pontosabbnak mondható, mint az $F_{b}$ esetében, hiszen a sorja szeparációja a furattól további hibát visz a rendszerbe, azonban a sorjamentes terület egyértelmüen és közvetlenül alkalmazható. Az ideális etalon furat alkalmazásakor a technológiából adódó alak- és méretpontatlanságok hibaként jelennek meg a mérőszámban, ezért becslése a körillesztéssel támogatott számításokkal javasolt.

$$
F_{b f}=\frac{A_{\text {free }}}{A_{\text {nom }}} \cdot 100
$$

Ahol: $F_{b f}(\%)$ a sorjamentes faktor, $A_{\text {nom }}\left(\mathrm{mm}^{2}\right)$ a nominális furat területe és $A_{\text {free }}\left(\mathrm{mm}^{2}\right)$ a sorjamentes területe a furatnak.

A felsorolt (i) egyszerű, (ii) hosszúság és (iii) területalapú sorjajellemzési módszereken és méröszámokon felül olyan sorját jellemző összetett mérőszámok fejlesztése is történt számos kutató által, melyek a sorján kívül egyéb makrogeometriai fúrásindukált hibát (pl.: delaminációt) is figyelembe vesznek [7], [14], [22], [23].

A jövőben várhatóan lesznek törekvések a szálerősített polimer kompozitok sorjamérési módszereinek és mérőszámainak egységesítésére, valamint szabványban történő rögzítésére. Ezen felül várhatóan olyan komplex mérőszámok alkalmazása fog elterjedni, amelyek teljesebb képet nyújtanak a sorja karakterisztikájáról és mennyiségéről, illetve további információval szolgálnak a szerelhetőségre és a sorja eltávolítási operációk energiaigényére.

\section{4. Összefoglalás}

A jelen áttekintő cikkben a szénszállal erősített polimer (CFRP) kompozitok fúrása során keletkező sorja mérőszámainak összefoglalása és elemzése történt. Az egyszerű sorjamérőszámok $\left(I_{b}, N_{b}, F_{b n}\right)$ gyors és egyszerü kiértékelést tesznek lehetővé, azonban az $I_{b}$ eredménye erősen szubjektív, $N_{b}$ és $F_{b n}$ nem ad információt a sorjakarakterisztikáról.

A hosszúság alapú sorjamérőszámok $\left(L_{b}, H_{b}, H_{b z}, W_{b}, F_{b c}\right)$ alkalmazása egyszerü és költséghatékony, azonban sok esetben a méröszámok csak a sorjaképződmény egy részletét jellemzik, ezért érdemes a sorjaképződmények mérőszámainak átlagolását is elvégezni a teljes sorja jellemzésének okán. Különböző méretű geometriák nem összehasonlíthatók segítségükkel, ezért javasolt egy nominális értékhez történő arányosításuk.

A területalapú sorjamérőszámok $\left(A_{b}, A_{b g}, F_{b}, F_{b f}\right)$ alkalmazása információértékük miatt gyakori a kutatók körében, hiszen ezen mérőszámok a teljes sorja mennyiségére adnak utalást. $F_{b}$ és $F_{b f}$ egy nominális értékhez történő arányosítása miatt összehasonlíthatóságot tesz lehetővé a különböző geometriák között. Azonban a sorjakarakterisztikára vonatkozóan ezen mérőszámok sem hordoznak releváns információt. 


\section{Köszönetnyilvánítás}

A kutatás részben az Innovációs és Technológiai Minisztérium OTKA-PD20-134430 kódszámú Posztdoktori Kutatási Projekt és az ÚNKP-20-3 és ÚNKP-20-2 kódszámú Új Nemzeti Kiválóság Programjainak a Nemzeti kutatási, fejlesztési és innovációs alapból finanszírozott támogatásával készült.

\section{Irodalomjegyzék}

[1] A. Toldy et al.: The Effect of Multilevel Carbon Reinforcements on the Fire Performance, Conductivity, and Mechanical Properties of Epoxy Composites, Polymers, Feb. 2019, Vol. 11, No. 2, Art. No. 2, DOI: 10.3390/polym11020303.

[2] N. Forintos and T. Czigany: Multifunctional application of carbon fiber reinforced polymer composites: Electrical properties of the reinforcing carbon fibers - A short review, Compos. Part B Eng., Apr. 2019, Vol. 162, pp. 331-343, Doi: 10.1016/j.compositesb.2018.10.098.

[3] J. Xu, M. Ji, J. Paulo Davim, M. Chen, M. El Mansori, and V. Krishnaraj: Comparative study of minimum quantity lubrication and dry drilling of CFRP/titanium stacks using TiAIN and diamond coated drills, Compos. Struct., 2020, Vol. 234, p. 111727, DOI: 10.1016/j.compstruct.2019.111727.

[4] K. M. John and S. Thirumalai Kumaran: Backup support technique towards damage-free drilling of composite materials: A review, Int. J. Lightweight Mater. Manuf., 2020, Vol. 3, No. 4, pp. 357-364, DOI: 10.1016/j.ijlmm.2020.06.001.

[5] H.-M. Beier, Handbuch Entgrattechnik: Wegweiser zur Gratminimierung und Gratbeseitigung für Konstruktion und Fertigung. Hanser, 1999.

[6] G. He, H. Li, Y. Jiang, X. Qin, X. Zhang, and Y. Guan: Helical milling of CFRP/Ti-6Al-4V stacks with varying machining parameters, Trans. Tianjin Univ., Jan. 2015, Vol. 21, No. 1, pp. 56-63, DOI: 10.1007/s12209-015-2360-9.

[7] R. Voß, M. Henerichs, S. Rupp, F. Kuster, and K. Wegener: Evaluation of bore exit quality for fibre reinforced plastics including delamination and uncut fibres, CIRP J. Manuf. Sci. Technol., 2016, Vol. 12, pp. 56-66, DOI: 10.1016/j.cirpj.2015.09.003.

[8] M. Li, M. Huang, X. Jiang, C. Kuo, and X. Yang: Study on burr occurrence and surface integrity during slot milling of multidirectional and plain woven CFRPs, Int. J. Adv. Manuf. Technol., Jul. 2018, Vol. 97, No. 1, pp. 163-173, DOI: 10.1007/s00170-018-1937-6.

[9] J. Kim, Y.-B. Kim, J. W. Seo, and H. W. Park: Deburring drilled holes in CFRP composites with large pulsed electron beam (LPEB) irradiation, J. Manuf. Process., Apr. 2019, Vol. 40, pp. 68-75, DOI: 10.1016/j.jmapro.2019.03.001.

[10] D. Wang, F. Wang, Z. Wang, G. Bi, and Q. Wang: Influence of Dynamic Change of Fiber Cutting Angle on Surface Damage in CFRP Milling, in Recent Advances in Intelligent Manufacturing, Singapore, 2018, pp. 428-439, DOI: 10.1007/978-981-13-2396-6_40.

[11] N. Geier, T. Szalay, and I. Biró: Trochoid milling of carbon fibre-reinforced plastics (CFRP), Procedia CIRP, 2018, Vol. 77, pp. 375-378, DOI: 10.1016/j.procir.2018.09.039.

[12] N. Sugita, L. Shu, K. Kimura, G. Arai, and K. Arai: Dedicated drill design for reduction in burr and delamination during the drilling of composite materials, CIRP Ann., 2019, Vol. 68, No. 1, pp. 89-92, DOI: 10.1016/j.cirp.2019.04.094.

[13] S. Dong, W. Liao, K. Zheng, J. Liu, and J. Feng: Investigation on exit burr in robotic rotary ultrasonic drilling of CFRP/aluminum stacks, Int. J. Mech. Sci., 2019, Vol. 151, pp. 868-876, DOI: 10.1016/j.jimecsci.2018.12.039.

[14] A. Hrechuk, V. Bushlya, and J.-E. Ståhl: Hole-quality evaluation in drilling fiber-reinforced composites, Compos. Struct., 2018, Vol. 204, pp. 378-387, DOI: 10.1016/j.compstruct.2018.07.105.

[15] D. Poór, N. Geier, C. Pereszlai, and N. Forintos: A pilot experimental research on drilling of CFRP under tensile stress. In: Zlatan Car, Jan Kudláček (eds.), Proceedings of International Conference on Innovative Technologies, IN-TECH 2019, 2019, pp. 126-129.

[16] K. M. Park, R. Kurniawan, Z. Yu, and T. J. Ko: Evaluation of a hybrid cryogenic deburring method to remove uncut fibers on carbon fiber-reinforced plastic composites, Int. J. Adv. Manuf. Technol., Apr. 2019, Vol. 101, No. 5, pp. 15091523, DOI: 10.1007/s00170-018-3045-z.

[17] S. Gaugel et al.: A comparative study on tool wear and laminate damage in drilling of carbon-fiber reinforced polymers (CFRP), Compos. Struct., 2016, Vol. 155, pp. 173-183, DOI: 10.1016/j.compstruct.2016.08.004.

[18] J. Xu, Q. An, X. Cai, and M. Chen: Drilling machinability evaluation on new developed high-strength T800S/250F CFRP laminates, Int. J. Precis. Eng. Manuf., Oct. 2013, Vol. 14, No. 10, pp. 1687-1696, DOI: 10.1007/s12541-0130252-2.

[19] C. Pereszlai and N. Geier: Comparative analysis of wobble milling, helical milling and conventional drilling of CFRPs, Int. J. Adv. Manuf. Technol., Feb. 2020, Vol. 106, No. 9, pp. 3913-3930, DOI: 10.1007/s00170-019-04842-4.

[20] N. Geier, G. Póka, and T. Szalay: Direct monitoring of hole damage in carbon fibre-reinforced polymer (CFRP) composites, IOP Conf. Ser. Mater. Sci. Eng., 2018, Vol. 448, p. 012003, DOI: 10.1088/1757-899X/448/1/012003.

[21] N. Geier, T. Szalay, and M. Takács: Analysis of thrust force and characteristics of uncut fibres at non-conventional oriented drilling of unidirectional carbon fibre-reinforced plastic (UD-CFRP) composite laminates, Int. J. Adv. Manuf. Technol., Feb. 2019, Vol. 100, No. 9, pp. 3139-3154, DOI: 10.1007/s00170-018-2895-8.

[22] P. Masek, P. Zeman, P. Kolar, and F. Holesovsky: Edge trimming of C/PPS plates, Int. J. Adv. Manuf. Technol., Mar. 2019, Vol. 101, No. 1, pp. 157-170, DOI: 10.1007/s00170-018-2857-1.

[23] F. Wang, X. Wang, X. Zhao, G. Bi, and R. Fu: A numerical approach to analyze the burrs generated in the drilling of carbon fiber reinforced polymers (CFRPs), Int. J. Adv. Manuf. Technol., Feb. 2020, Vol. 106, No. 7, pp. 3533-3546, DOI: $10.1007 / \mathrm{s} 00170-019-04872-y$. 